NBER WORKING PAPER SERIES

\title{
CARBON MOTIVATED BORDER TAX ADJUSTMENTS: OLD WINE IN GREEN BOTTLES?
}

\author{
Ben Lockwood \\ John Whalley \\ Working Paper 14025 \\ http://www.nber.org/papers/w14025
NATIONAL BUREAU OF ECONOMIC RESEARCH
1050 Massachusetts Avenue \\ Cambridge, MA 02138
}

May 2008

The views expressed herein are those of the author(s) and do not necessarily reflect the views of the National Bureau of Economic Research.

NBER working papers are circulated for discussion and comment purposes. They have not been peerreviewed or been subject to the review by the NBER Board of Directors that accompanies official NBER publications.

(C) 2008 by Ben Lockwood and John Whalley. All rights reserved. Short sections of text, not to exceed two paragraphs, may be quoted without explicit permission provided that full credit, including $\odot$ notice, is given to the source. 
Carbon Motivated Border Tax Adjustments: Old Wine in Green Bottles?

Ben Lockwood and John Whalley

NBER Working Paper No. 14025

May 2008

JEL No. F13,F18,Q56

\begin{abstract}
$\underline{\text { ABSTRACT }}$
We discuss emerging proposals for border tax adjustments (BTAs) to accompany commitments to reduce carbon emissions in the EU, the US and other OECD economies. The rationale offered for such border adjustment is that various entities, such as the EU, if making commitments to reduce emissions which go beyond those undertaken in other regions of the world, impose added costs on domestic producers which create a competitive disadvantage for them. Some form of remedy is viewed as reasonable to maintain the competitiveness of domestic industries when responding to global environmental problems. In this paper, we argue that despite its current carbon manifestation, the issue of border tax adjustments and both their rationale and their effects on trade are not new and, despite the present debate (which seems to overlook older literature), have arisen before. Earlier debate on border tax adjustments occurred at the time of the adoption of the Value Added Tax (VAT) in the EU as a tax harmonization target in the early 1960's. But academic literature of the time showed that a change between origin and destination basis in the VAT would be neutral and hence the use of a destination based tax in the EU to accompany the VAT offered no trade advantage to Europe. Here we argue that essentially the same arguments also apply for carbon motivated BTAs, and in the current debate there seems to be a misconception between price level effects and relative price effects stemming from a BTA, which needs correcting. We also argue that the impact of border tax adjustments should be viewed as independent of the motivation of the adjustments.
\end{abstract}

\author{
Ben Lockwood \\ Department of Economics \\ University of Warwick \\ b.lockwood@warwick.ac.uk \\ John Whalley \\ Department of Economics \\ Social Science Centre \\ University of Western Ontario \\ London, Ontario N6A 5C2 CANADA \\ also NBER, CIGI, and CESifo \\ jwhalley@uwo.ca
}




\section{Background and Introduction}

This piece discusses emerging proposals for border tax adjustments (BTAs) to accompany commitments to reduce carbon emissions in the EU, the US and other OECD economies. ${ }^{2}$ The commitments at issue, with the exception of the EU, are those which may possibly be made in the future and, in turn, these may be either internationally negotiated or undertaken unilaterally. However, carbon motivated BTAs could either be an integral part of a multilaterally negotiated package or unilaterally declared commitments, or simply follow on after the initial negotiations or commitment.

Current thinking in global environmental policy circles is that due to the cost implications for domestic producers of emission reduction initiatives, BTAs would potentially form part of what might emerge from Copenhagen in 2009 as part of the post Kyoto world/ UNFCCC post-Bali process. These possibilities are in addition to what is under discussion currently in the EU and the US. The rationale offered for such border adjustments is the added costs to domestic producers involved which are thought to pose a competitive disadvantage for them. Some form of remedy is viewed as reasonable to maintain the competitiveness of domestic industries when responding to global environmental problems with emissions reduction efforts which raise energy prices.

\footnotetext{
${ }^{2}$ Currently in the EU, there are commitments which have been made by the European Commission for a 20\% reduction in emissions by 2020 and a 20\% target for use of renewables, with emissions reductions to go to $30 \%$ if other regions match (see Ismer \& Neuhoff (2007)). These emission reductions are seen in the EU as going farther than in any other entity globally and hence, a system of border adjustments involving tariffs on imports and export subsidies is seen as a way of offsetting the competitiveness effects which are involved. The EU programmes seem likely to be implemented in ways which are highly sectorally focused, with a major emphasis on power generation, aluminum, cement and steel. In the US there is discussion of similar potential legislation even though the US has undertaken no formal commitments at this stage. Proposals along these lines are contained in the Lieberman-Warner Bill (see Brewer (2008)), which by 2019 would mandate similar US actions.
} 
The potential, therefore, is for a world to evolve in which large entities in the OECD simultaneously go green and protectionist at the same time with border tax adjustments as the new protectionism and these being seen as a necessary accompaniment to commitments to carbon emission reductions which raise energy prices and impose added costs on domestic producers. Perhaps not surprisingly, this prospect is seen instead by trade economists as a potential threat to the functioning of the global trading system. Those in lower income countries in Africa, South America, Asia and also in Eastern Europe (and especially Russia) also see such measures as a threat to their wellbeing, which will restrict their market access and cause major dislocation of their trade.

In this paper, we argue that despite its current carbon manifestation, border tax adjustments and both their rationale and effects on trade is hardly a new topic, despite the present debate which seems to overlook older literature. We also argue that the older analytical literature on border tax adjustments is highly relevant to current debate on their recent carbon related manifestation. Earlier debate on border tax adjustments occurred following the adoption of the Value Added Tax (VAT) in the EU as a tax harmonization target in the early 1960's. ${ }^{3}$ The European harmonized VAT, following the 1958 Neumark Committee, was agreed to be administered on a destination basis and hence involve taxes on imports and a rebate of taxes on exports. This arrangement was, however, viewed initially by US business as conferring a trade advantage on the EU. The argument was that under the VAT American exports to the EU had to cross a tariff barrier, whereas EU exports to the US faced no such barrier because of the remission of domestic taxes. However, this line of argument from the policy community was also countered in the academic literature at the time. This was because the difference between an origin and

\footnotetext{
${ }^{3}$ See Dosser (1967), Shibata (1967), Krauss \& Johnson (1972)
} 
destination basis is simply that between a production and consumption tax, both of which in the broadly based (static, no labor-leisure choice) case are neutral, with no direct effects on trade. The argument was that a move from an origin to a destination basis in the VAT would simply have the effect of changing the price level (or exchange rate) in a model where taxes are broadly based on all commodities. A change between origin and destination basis in the VAT would have no protective effect, and hence the use of a destination based tax in the EU to accompany the VAT offered no trade advantage to Europe. This analytical argument, at the time, caused a change in policy approach from the US, who had been pushing for a negotiation on border tax adjustments as part of the then emerging Tokyo Round in the GATT of the day. Since those days, the border tax adjustment issue has not been forcefully raised in any policy debate.

Here we argue that essentially the same arguments also apply for today's carbon motivated BTAs, and in the current debate there seems to be a misconception between the price level effects and relative price effects stemming from a BTA, which needs correcting. We also argue that the impact of border tax adjustments should be viewed as independent of the motivation of the adjustment. BTAs can be motivated by any one of any number of issues including differential labor standards, social programs, government provided health care, and other considerations. The fact that the current debate is driven by carbon emission reductions should be seen as largely irrelevant to an assessment of the impacts of the border adjustments themselves. And if the BTAs accompanying carbon emissions reductions are broadly based, the discussion of earlier years still applies. There will be a price level effect as well as a relative price effect and the price level effect will have no real effects on trade flows or domestic industry, despite their intent. 
In discussing carbon motivated BTAs, one thus seemingly has to differentiate between the variance created in tax rates across industries and products from BTA impacts from the price level effects which occur uniformly across all industries. However, we also note that even in cases involving product or sector specific BTAs, one can again produce neutrality propositions for the tax basis change if there is sufficient sector specificity in inputs. In essence, we argue that the old literature on BTAs has been lost in the current debate on carbon motivated border tax adjustments. It needs to be rediscovered and there needs to be a clearer articulation of the likely effects that their use would generate. 


\section{The Debate on Carbon Motivated BTAs}

The issue of carbon motivated border tax adjustments initially surfaced as part of the general discussion of leakage associated with country or regional carbon commitments which went unmatched by others. Most of the debate has centered on the WTO compatibility of such measures (De Cendra (2006), Demaret \& Stewardson (1994), Goh (2004) and Ismer \& Neuhoff (2007)). Relatively little of it has focused on what the impacts of these border adjustments would actually be, although Ismer \& Neuhoff (2007) provide an initial partial equilibrium analysis of impacts but this does not focus on the price level or exchange rate effects stressed both here and in earlier border tax adjustment literature.

The background to this now growing debate is that in a world where different entities move at different speeds in undertaking carbon emission reductions, and do so from different initial standing points, the result will be unequal carbon prices across various countries. In current discussion of the EU emissions trading scheme, the competitiveness and leakage effects of unilateral climate changes have thus been a major topic for discussion. ${ }^{4}$

The leakage discussion focuses on how one country may reduce emissions and other countries increase emissions as a result. The claim is that along with these effects go competitive disadvantages to domestic industry associated with leakage, and these competitiveness effects become critical in securing agreement to the emissions reductions. The need to offset these competition effects has been portrayed as a way of remedying leakage, although in reality they become tax induced offsets for cost increases faced by domestic producers. Although not explicitly discussed as part of the BTA effort,

\footnotetext{
${ }^{4}$ See Dröge \& Kemfert (2005).
} 
commitments to achieve targets for use of renewables (wind, solar) could also involve BTAs due to similar effects. In passing, we note that such effects need not be made only through BTAs; they are only one such possible instrument. Changing corporate tax rates by sector, R\&D tax credits, depreciation rates and many other tax instruments provide other possibilities, but they seemingly have not been discussed.

Among the countries (or regions) who have embarked on what they see as stricter climate policies, emissions reductions in these countries are seen as generating accompanying leakage through a shift in consumption from carbon based goods towards now cheaper importable substitutes allowing for more carbon intensive production in regions without comparable carbon pricing. Equally, relocation of production to areas or regions without carbon pricing is seen as a possible outcome. Furthermore, in a world of unequal cross-country carbon prices, BTAs are claimed to give more certainty for those involved in emissions reduction initiatives, especially for long run investments in various key sectors.

This set of arguments has been made centrally in the EU with their emissions trading scheme ${ }^{5}$, but also seems likely to follow in Australia and New Zealand and some regions and provinces within the US and Canada where emissions reduction policies are either in place or under discussion. In the EU, there have also been strategic sectors which have been identified as leading the emission reduction strategy and the need for certainty of the time profile of carbon pricing when long term investments are made is seen as a prime motivator of adjustments at the border which preserve international

\footnotetext{
${ }^{5}$ But although EU emissions policy is seen in this way in Europe, in many ways the unilateral commitments undertaken by China out to 2020 go beyond those in Europe (See Tian \& Whalley (2008)).
} 
competitiveness. These sectors include cement, iron \& steel, aluminum, pulp \& paper, refineries and fertilizer.

These pressures are seen by some in OECD countries as inevitably leading to border adjustments. The claim from those supporting such initiatives in the EU is that the negative impacts of unilateral carbon reduction initiatives on the international competitiveness of industries can only be addressed by balancing cost differentials at the border.

There are two ways that have been advanced to offset the leakage and cost effects involved. One is that imported goods would be taxed at the border in ways which reflect the cost of the emissions trading were they to be produced in the home market they are entering. This would involve border tax adjustments between countries, and the central debating point has been the WTO compatibility of such measures. There are, however, no clear definitions or calculations as to the relevant Dollar or Euro amounts which are to be used in such adjustments, or even how such calculations would be made. One of the difficulties is that border adjustments used to offset cost disadvantages imposed on domestic producers would reflect added production costs not only occurring directly but also indirectly (ie - emissions involved in the production of the steel which go into a car as well as carbon emitted assembling the car). Also, the chain of component inputs would themselves need to be followed across (potentially many) borders. Another complication is that such calculations should presumably be relative to costs abroad and not only based on home markets. There would thus be gradations of adjustments across supplying countries, along with potentially complex rules of origin as now occur in preferential trade agreements. Thus, this evolving debate on import taxes is but part of discussion of 
wide ranging new climate change programs which, even in the EU and the US, still need more clarification in terms of practical implementation.

An alternative approach to BTAs which has been suggested is to use tax equivalents based on enforcement of emissions allowance trading for all importers. US debate focuses on this approach. Under this, any importer of products would need to buy emissions rights domestically to meet required offsets, and exporters could sell some of their emissions permits acquired for production to gain offset. At issue here is also the much wider question of whether or not emissions reductions commitments should be focused on emissions implied by geographical location of production, or geographical location of consumption. These are also issues for the post-Bali negotiations scheduled to conclude in Copenhagen in 2009. Chinese negotiators, for instance, have raised the key issue of carbon emission embedment in exports; arguing that around 35\% of China's emissions derive from exports which are other countries’ consumption.

This emissions allowance approach to BTAs is currently being taken in the US in two different bills before the Senate which introduce the concept of international reserve allowances which are to be issued by the US government (See Brewer (2008)). Under this scheme, importers will need to buy emissions rights for the carbon content of their imports even though imports are produced abroad. The claim is that this will reduce leakage effects by adjusting the prices of imports to reduce substitution from abroad. Also, exporters will be able to sell some of their emissions rights acquired for production. The effect is similar to the BTA above; in both cases there is a border adjustment and the border adjustment will form part of trade policy. 
The state of the debate is therefore that there are commitments and proposals currently pending in the EU on these matters and also discussion of alternative possible actions in the US and vaguer possibilities raised both elsewhere and multilaterally. The claim is that these border adjustments will level the playing field for domestic producers and provide an offset to the non-competitive effects involved by taking on various unilateral or negotiated commitments towards carbon emissions reduction. The current presumption is that such schemes will arise in the post-Bali UNFCCC negotiations as a claimed necessary part of an implementable global climate change regime (see Walsh \& Whalley (2008)). 


\section{The Older Debate on Border Tax Adjustments}

Our observation in this paper is that current debate on carbon motivated border tax adjustments, either using international reserve allowances or formal border adjustments, could usefully recognize fully both previous debate and pre-existing literature on border tax adjustments. As was mentioned in the introduction, the origins of earlier border tax adjustment discussion go back to the formation of the European Union and the commitment in the Treaty of Rome to sequenced integration. Under the Treaty of Rome there was first to be a customs union for the elimination of tariffs on trade between member countries and the adoption of a common external tariff to be followed by a tax union in which there would be harmonization of both tax structure and rates, and eventual full economic and monetary union (see Dosser (1967) and Shibata (1967)). The tax union process in the EU as it evolved in the late 1950's initially focused on indirect taxes and discussion on the adoption of a common harmonization instrument. The first tax chosen was the value added tax, which in turn was to replace all pre-existing turnover or indirect taxes in all EU countries. The idea was eventually for there to be first base harmonization and then rate harmonization, which has not yet occurred.

With the adoption of the VAT, however, there arose the central issue of the agreed basis for the commonly adopted tax. Was the tax to be based on production or consumption? If based on production, the tax would apply to exports, with no rebate at the border and imports would enter EU countries tax free - the so-called origin basis for the value added tax. With a tax basis using consumption, taxes would be applied on imports as they entered each of the EU countries and taxes would also be rebated on 
exports - the so called destination basis for the value added tax. The choice between these two bases became a major topic within the harmonization debate within Europe, and in the late 1950's it was resolved by the report of the Neumark Committee (Neumark (1958)), which recommended in favor of the use of a destination basis for a harmonized European VAT. The Neumark Committee also recommended that the EU eventually move to a restricted origin basis, where there would be a destination basis applied to trade outside of the EU, but an origin basis applying to trade within the EU. The idea was to remove fiscal frontiers between EU states by using the origin basis internally. With the Neumark Report the destination basis became the common harmonization mechanism for the value added tax as it was introduced in individual EU countries; who in turn followed the VAT first introduced in France in 1954.

With the adoption of the destination basis in Europe for the to be harmonized VAT, the original European countries, and later acceding countries including the UK, Ireland, Denmark, and Sweden then began to apply tax measures at the border. Imports were subject to tax and input taxes on exports were rebated.

However, there was also growing opinion in the US business community that this harmonized tax structure in the EU involved intervention in trade which was disadvantageous to the US. At this time in the US, however, there was no federal broadly based indirect or sales tax, as is still the case since the US tax system is characterized by heavier reliance on corporate and income taxes, with no such federal tax. The argument was that US exports had to cross a tax barrier in order to penetrate EU markets since taxes were applied to imports coming into the EU while EU exports left the EU tax free. As a result, in the mid 1960's and after the conclusion of the GATT Kennedy Round in 
1967 (but before the launch of the Tokyo Round in 1973), pressure built in the US for a border tax adjustment negotiation to be included in then emerging trade round in the GATT. There was substantial debate about the GATT compatibility of such measures. GATT Article 3 clearly rules out the use of tax measures which give advantage to domestic products and there was debate as to whether or not the use of the destination basis in the EU VAT was a violation of Article 3. There was growing pressure on the US government to initiate a dispute settlement case on this issue, and focused specifically on alleged Article 3 violations.

What transpired, however, was that no dispute settlement case was initiated and ultimately, no GATT negotiation took place on this issue in the Tokyo Round. This was in large part because of contributions from the academic community which stressed that, in a very simple world where all consumption goods are taxed at the same rate and there is no savings and no labor-leisure choice, a movement between an origin and a destination basis in a VAT or sales tax will have no real effects on trade, production or consumption (see Dosser (1968), Krauss \& Johnson (1972), Shibata (1967)). This is despite the appearance of there being a tax barrier to imports in the importing country and a tax subsidy to exports under a destination basis compared to an origin basis. The reason is that neither form of tax changes the relative prices of goods to either consumers or producers (budget constraints show no change in slope) and hence moving from one basis to the other has no effect if trade is balanced. It simply makes no difference whether one taxes consumption or production.

The argument made was the following. The difference between an origin and a destination basis is that between a tax on production and a tax on consumption. Assuming 
that the taxes involved are broadly based and a single rate is used (and, for now, either a sales or value added tax), either way they are administered there will be no effects either on the slope of the budget constraint faced by consumers or on the relative prices of goods faced by the firms who produce them. Therefore a move from one basis to another would be neutral in terms of its impacts on trade, production or consumption. If a change between tax bases occurred (origin to destination or vice versa) something would adjust so that no changes in relative prices across country goods resulted. This could be an adjustment in the two country price levels, wage rates, and/ or exchange rates. In this sense, neutrality (no real effects) of trade production or consumption effects would prevail under a tax basis change.

Put slightly differently, border tax adjustments in such cases would have no real effects since their intended impacts would be fully offset by changes in exchange rates, price levels across countries, or wage rates (see also Grossman (1980), Whalley (1979), and Lockwood, Meza \& Myles (1994)). This idea was explicitly set out in analytic form in Krauss \& Johnson (1972), Whalley (1979), Grossman (1980), and Lockwood et al (1994). They all showed formally that in simple models with trade, if there was an exchange rate that was endogenously determined then a change from one tax basis to another would simply be offset by a change in the exchange rate with no real effects on trade, production or consumption. Equally, in models where there were flexible prices across countries or flexible wage rates within countries and with labor being immobile 
between countries, then again changes in tax basis (origin to destination or vice versa) would simply be offset by changes in the real wage or changes in the price level. ${ }^{6}$

Whichever way the analysis proceeded, there was simply no effect on trade flows because the move between the origin and destination basis, while in simple cases having price level effects across countries, has no relative price effects across goods. These arguments were then further elaborated on in later papers by Whalley (1979) and by Lockwood et al (1994) which also examined when such neutrality would break down.

It is all of this analysis of the impacts of border tax adjustments which seems to have been lost in the current debate on carbon motivated border tax adjustments. The implication, however, is that if carbon motivated border tax adjustments occur which are common across all products then independently of the motivation for the border adjustment they will have no real effects on trade, and importantly offer no protection to domestic producers and will do nothing to address the leakage issues that, in the European case, ostensibly motivate them.

In the border tax literature, to our knowledge there has been no discussion of any tax adjustments being used for any purpose outside of the VAT except for this recent debate on carbon based border tax adjustments. One could, however, also argue for border tax adjustments to compensate for any type of competitive disadvantage seemingly imposed on domestic producers. This could be country specific regulations such as minimum wages, or country specific provision of government programs such as health care and education; indeed, any number of other factors beyond emissions commitments could be argued to be needed to be offset by some form of border tax

\footnotetext{
${ }^{6}$ This border tax argument is closely related to arguments made in the 1930's by the economist Abba Lerner that a tariff and export subsidy at the same rate have no effects on trade flows and are equivalent to a devaluation. This is sometimes referred to as a variant of so called Lerner Symmetry.
} 
adjustment. There is thus, also in our view, nothing uniquely carbon related in these arguments being made in the current debate.

We would thus argue that on the basis of earlier literature, one has to separate out the motivation for the border tax adjustments from an assessment of the actual impacts that they will have. And importantly, their impact would seem to be largely independent of their motivation. Hence, in assessing the impacts of carbon emission reduction motivated BTAs, one can, in effect, set aside the carbon motivation component when discussing their impact. And in simple models, as with the VAT, they will have no real effects.

If the border tax adjustments are sector specific as seems likely in the carbon case, one can seemingly argue that the relative price effect is the dominant component of the BTA impact. However, whether or not such BTAs will have significant effects depends on the implicit model used for evaluation of the counter-factual case following the introduction of a BTA. One could build models where there are sector specific forms of labor and the sector specific wage rates would be the adjusting mechanism in response to a BTA reestablishing neutrality, even in sectorally focused border tax adjustments. Thus, again there seemingly need be no real side effects to follow even from sector specific BTAs in such models. Whether such models are realistic, and how long and short run effects enter with differing forms of sector specificity would thus be key. Hence, we would argue that even with sector specific BTAs, the older literature on border tax adjustments can still be applied directly to the carbon motivated adjustments that are the subject of debate today and may continue to take one in a direction missing from current debate, even recognizing the likely sector specificity of carbon motivated BTAs. 


\section{Concluding Remarks, and the Implications of Older Literature for Carbon Motivated BTAs}

The implications of this discussion of older border tax adjustment literature for carbon motivated BTAs seems to us to be clear. There is much discussion of the need to offset the competitive disadvantages which are associated with commitments on carbon emissions reductions of the type currently proposed in the EU and possibly eventually in the US, and legislation is pending on these matters in both cases. However, one must recognize the older literature which stresses the potential neutrality of such tax measures, and seemingly separate out the price level and relative price effects involved in assessing the impacts of BTAs. One also has to separate out the motivation for their use from an assessment of their actual impact. Their potential price level effects could likely have little or no impacts on trade flows, and even offer no offset to either leakage or competitive disadvantage from cost impacts of emissions commitments on domestic producers.

Hence, what may appear as an offset to competitiveness effects of environmental policies may not be so. Indeed, the seeming relative price effects themselves may not even have an impact on trading patterns if there is sufficient specificity in the production technology. If there are rents involved, either with sector specific wage rates or through specific factors which would absorb the effects of the tax change again, there would again be no effect on trade. Finally, and in repetition of earlier discussion, BTAs are not the only instrument available for the chosen objectives; corporate tax manipulation of rates and structure is another. 
All of these issues thus seemingly have to enter any evaluation of what carbon motivated BTAs might actually achieve. We also argue that one has to separate out the motivation for these adjustments from discussion of what the actual impacts of these adjustments might be, in contrast to current debate. 


\section{Bibliography}

Asselt, Harro van \& Frank Biermann (2007) "European Emissions Trading and the International Competitiveness of Energy-Intensive Industries: A Legal and Political Evaluation of Possible Supporting Measures” Energy Policy 35 (1), pp 497-507.

Brewer, T. (2008) "US Climate Policy - Trade Policy Intersections, Current Status, Prospects and Implications for Carbon Leakage” Presentation to the Climate Strategies Carbon Leakage Workshop, February $4^{\text {th }}$, Paris.

De Cendra, Javier (2006) “Can Emissions Trading Schemes be Coupled with Border Tax Adjustments? An Analysis Vis-à-vis WTO Law” Review of European Community and International Environmental Law 15 (2), pp 131-145.

Demailly, Damien \& Philippe Quirion (2005) “Leakage from Climate Policies and Border Tax Adjustment: Lessons from a Geographic Model of the Cement Industry" www.centre-cired.fr/perso/quirion/demailly_quiron_venice_final.pdf

Demaret, Paul \& Raoul Stewardson (1994) "BTA Under GATT - Trade, Environment and the Future” Washington, D.C.

Dosser D. (1967) “Economic analysis of tax harmonization” in: C.S. Shoup, ed., Fiscal harmonization in common markets, vol. I, Theory, Columbia University Press, New York.

Dröge, S. \& C. Kemfert (2005) “Trade Policy to Control Climate Change: Does the Stick Beat the Carrot?” Quarterly Journal of Economic Research 74 (2), pp 235-248.

Fauchild, Ole Kristian (1998) “Environmental Taxes and Trade Discrimination” Olso.

Goh, Gavin (2004) “The World Trade Organization, Kyoto and Energy Tax Adjustments at the Border” Journal of World Trade 38 (3), pp 395-423.

Grossman, Gene M. (1980) “BTA: Do They Distort Trade” Journal of International Economics No. 10, pp 117-128.

Hufbauer, Gary C. (1996) “Fundamental Tax Reform and Border Tax Adjustments” Washington D.C.

Ismer, R. and K. Neuhoff (2007) “Border Tax Adjustment: A Feasible Way to Support Stringent Emission Trading” European Journal of Law and Economics 24, pp 137-164.

Krauss, M. B. \& H. G. Johnson (1972) “The Theory of Tax Incidence: A Diagrammatic Analysis,” Economica, Vol. 39(156), London School of Economics and 
Political Science, pp 357-82.

Lockwood B., Meza D. \& Myles G. (1994) "When are origin and destination regimes equivalent?” International Tax and Public Finance, 1 (1), pp 5-24.

Neumark Report (1963) "Report of the fiscal and financial committee" in: The EEC reports on tax harmonization, International Bureau of Fiscal Documentation.

Shibata, H. (1967) "The theory of economic unions: A comparative analysis of customs unions, free trade areas, and tax unions" in: C.S. Shoup, ed., Fiscal harmonization in common markets, vol. I, Theory, Columbia University Press, New York.

Tian Y. \& J. Whalley (2008) “China’s Unilateral Emissions Reduction Commitments, and Chinese Incentives to Participate in and Structure Global Environmental Negotiations" (unpublished).

Walsh, S. \& J. Whalley (2008) “The Global Negotiating Framework for Climate Change Mitigation” (unpublished).

Whalley, J (1979) "Uniform Domestic Tax Rates, Trade Distortions and Economic Integration” Journal of Public Economics, 11(2), pp 213-21. 